\title{
Mimaride Etkin Strüktürler Olarak Ahşap Izgara Kabuklar
}

\author{
Selen KOÇ${ }^{1}$, N. Volkan GÜR ${ }^{2}$
}

Öz

Ahşap ızgara kabuklar, serbest biçimleri nedeniyle karmaşık bir tasarım ve uygulama sürecine sahip olmasına rağmen; geniş açıklıkları minimum malzeme ile geçen en etkin taşıyıcı sistemlerden biridir. Çalışmada ahşap ızgara kabuk örneklerinin geçmişten günümüze gelişiminin, olumlu, olumsuz yönlerinin ve iki farklı tür (elastik ve rijit) ahşap ızgara kabuğun incelenmesi ve karşılaştırıması amaçlanmıştır. Bu kapsamda, inşa edildiği dönemde; tasarım ve uygulama açısından yeniliklere öncülük eden, farklı özelliklere sahip ahşap ızgara kabuk örnekleri seçilerek; bu örneklerin, tasarım, yapım yöntemi ve elemanları ile form oluşturma yöntemlerine ait verileri tablolar halinde sunulmuştur. Elde edilen sonuçlar ve yapılan değerlendirmelere göre, ahşap ızgara kabukların mimari ve yapısal açıdan gelişimine paralel olarak öneminin de giderek arttığı görülmektedir. Formun karmaşıklığı günümüzde sınırlayıcı bir faktör olarak görülmezken, yapısal karmaşıklığın artmasına bağlı olarak üretim sürecindeki zorluklar ve artan maliyet ahşap ızgara kabuk örneklerini müze, sergi salonları, spor alanları, vb. gibi sembolik yapılarla sınırlandırmıştır. Gelecekte, ahşap ızgara kabukların farklı konstrüksiyonları bir arada kullanan hibrid sistemler şeklinde uygulanabileceği öngörülmektedir.

Anahtar Kelimeler: Strüktür, ahşap ızgara kabuk, elastik ızgara kabuk, rijit ızgara kabuk, serbest-form.

\section{Timber Gridshells As Effective Structures In Architecture}

\begin{abstract}
Although timber gridshells have a complex design and construction process due to their free form; it is one of the most efficient structural systems to cover large-spans with minimum material. The study has aimed to analyze the evolution of timber gridshells over time, positive and negative aspects of using this system and to compare the samples of elastic and rigid gridshell structures. In this context, timber gridshell samples which owned unique design and constructional features during the period when they were built have been selected. Afterwards, design and construction methods and elements used, also form decision methods have been summarised in tables. According to the results obtained and the evaluations made, it has been seen that the importance of the timber grid shells is increasing in parallel with the architectural and structural development. Although the complexity of the form is not a limiting factor today, the difficulties in the production process and the increasing cost due to the increase in structural complexity have limited the timber gridshell samples to symbolic

\footnotetext{
${ }^{1}$ Gebze Teknik Üniversitesi, Fen Bilimleri Enstitüsü, Mimarlık Anabilim Dalı, Doktora Programı

${ }^{2}$ Mimar Sinan Güzel Sanatlar Üniversitesi, Mimarlık Fakültesi, Mimarlık Bölümü Igili yazar/Corresponding author: selenkocc@gmail.com
}

Bu çalışma, Mimar Sinan Güzel Sanatlar Üniversitesi, Fen Bilimleri Enstitüsü, Mimarlık Anabilim Dalı, Yapı Bilgisi Yüksek Lisans Programında tamamlanan "Ahşap Izgara Kabuk Strüktürlerin İncelenmesi" başlıklı yüksek lisans tezinden üretilmiștir.


structures such as museums, exhibition halls, sports fields, etc. It is expected that timber gridshells can be applied as hybrid systems that use different constructions together in the future.

Keywords: Structure, timber gridshell, elastic gridshell, rigid gridshell, free-form.

\section{Giriş}

Ahşap ızgara kabuklar, sürdürülebilirlik ve serbest biçim bağlamında çağdaş yapı sistemlerine; minimum malzeme kullanımı, hafiflik, yapısal verimlilik, hızlı ve uygun maliyetli yapım potansiyeline ek olarak geniş açıklıklı alanların oluşturulması gibi olumlu özellikleriyle önemli çözümler sunmaktadır (Naicu, Harris ve Williams, 2014). 20. yüzyılın ortalarında Frei Otto önderliğinde Hafif Yapılar Enstitüsü'nde ortaya çıkan ve sembolik yapılarla sınırlı kalan ahşap ızgara kabuklar, bilgisayar ve üretim teknolojilerinin gelişimiyle günümüzde geniş açıklıklı yapılarda etkili strüktürler olarak tekrar gündeme gelmiştir.

1962'den günümüze gelen süreçte üretilmiş birçok ahşap ızgara kabuğun gerçekleşmesinde, yapısal anlamda yeniliklere yol açan form bulma, bağlantı detayları gibi konularda çeşitli zorluklarla karşılaşılmıştır. Strüktür sisteminin etkinliğini belirleyen ölçütler; strüktür sisteminin en az malzeme, enerji ve giderle, öngörülen görevleri yerine getirmesi, uzun ömürlü ve dayanıklı olması, az bakım gerektirmesidir (Türkçü, 2017). Strüktür sisteminden beklenen özellikleri etkin bir şekilde karşılamalarına rağmen ahşap ızgara kabuklarda geçmişten günümüze, tasarım ve uygulama süreçlerinde değişimler görülmektedir.

Ortaya çıktığı dönemde 'ahşap ızgara kabuk (gridshell)' tanımı yalnızca sürekli ahşap elemanların itilip çekilerek oluşturulduğu elastik ızgara kabukları ifade ederken, günümüzde bu kavram prefabrike ahşap modüllerin sahada birleştirilmesiyle oluşturulan rijit ızgara kabukları da kapsamaktadır (Chilton ve Tang, 2016, s. xviii; Naicu vd., 2014).

Izgara kabuklar, kabukların yapısal ilkelerini takip eden ve uygulanan yüklere kendi şekilleri ile doğal olarak direnç gösteren taşıyıcı sistemlerdir (Grönquist vd., 2020, s. 6). İnce kabuklar gibi eğri geometrilere sahiptirler; ancak tek parça halinde dökülen sürekli yüzeyler yerine, ayrık yüzey özelliğinde, ince, hafif, uzun ve eğri çubuklardan oluşurlar. $\mathrm{Bu}$ strüktürlerde biçim, zeminde düz olarak yerleştirilen ince en kesitli ızgara elemanlarının (çubukların), itilerek ve çekilerek deforme edilmesiyle (elastik ızgaralar) veya prefabrike birimlerin/modüllerin sahada birleştirilmesiyle (rijit ızgaralar) oluşturulur. Yapım sırasında itme ve çekme kuvvetleriyle serbest biçimlerin rahatlıkla oluşturulmasına izin veren ahşap, hafif, yüklere ve eğilme momentlerine dayanıkı, kolay bükülebilen bir malzemedir (Charest vd., 2019, s. 4; Naicu vd., 2014). Ahşabın şekil değiştirmelere, gerilmelere, kırılmalara yol açan ve boyutunu etkileyen çeşitli yük kombinasyonlarına karşı koyma derecesini ve durumunu belirten mekanik özellikleri, Izgara kabuklar için de önemlidir.

21. yy'ın başından bu yana, yapısal modelleme ve dijital üretimdeki hızı gelişmeler, ahşap ızgara kabukların tasarım ve üretiminde önemli ilerlemeler meydana getirmiştir. Sayısal olarak kontrol edilen (CNC) fabrikasyonun geliştirilmesi de dahil olmak üzere, dijital tasarım ve imalat sürecinde bilgisayar destekli tasarım (CAD), bilgisayar destekli mühendislik (CAE), bilgisayar destekli imalat (CAM) gibi yazılımlardaki gelişmeler sayesinde ahşap ızgara kabukların sayısı artmaya devam etmektedir (Tang, Chilton ve Beccarelli, 2013, s.5-6). 
Bu çalışmada geçmişten günümüze son 50 yıl içerisinde farklı ülkelerde inşa edilmiş olan ahşap ızgara kabuk örnekleri; taşıyıcı sistem özellikleri, elemanları, yapı ölçeği, kullanılan yapım yöntemleri ve form oluşturma metotları, bağlantı detayları, ızgara sistemlerinde gözlenen yenilikler göz önünde bulundurularak incelenmiştir. Seçilen ahşap ızgara kabuk yapıları inşa edildiği dönemde yeniliklere öncülük etmiş olan ve ızgara kabukların gelişimini gösteren nitelikli yapılardır. Çalışmanın amacı, ahşap ızgara kabuk örnekleri üzerinden yapılan karşılaştırma ve değerlendirmeler ile bu strüktürlerin geçmişten günümüze gelişimini, olumlu, olumsuz yönlerini ve teknolojinin ızgara kabuklar üzerindeki etkilerini açıklamak ve gelecekteki kullanım potansiyellerini değerlendirmektir. Konuyla ilgili veri toplama aşamasında elde edilen teknik doküman ve bilimsel yayınlar karşılaştırmalı biçimde incelenmiştir.

\section{Ahşap Izgara Kabuklar}

Kabuk sistemler, antik çağlardan beri farklı malzemeler ve en uygun geometrilerle büyük açıklıkları geçmeyi sağlamışlardır (Türkçü, 2017). Endüstri Devrimi ile birlikte nüfusun giderek artması ve buna bağlı yapı intiyacının önemli ölçüde ilerlemesi, strüktürel gelişme için itici bir güç olmuştur.

Modern bir yapısal form olarak görülen ızgara kabuk, en basit haliyle, tarih boyunca insanlar tarafından sığınak inşa etmek için kullanıımıştır. Barınakların en basit haliyle, bükülmüş ve kesişen esnek dallardan oluşan ızgaralar olduğu söylenebilir (Şekil 1 (a)). Hayvan derileri veya dokuma kumaşla kaplanan bu ızgaralar, Moğol çöllerinde göçebe halkın katlanabilir ve taşınabilir bir barınak olarak geliştirdiği 'yurt' olarak tanımlanan yapılardır (Şekil 1 (b)) (Chilton ve Tang, 2016, s. 2; Songel, 2020, s. 237).
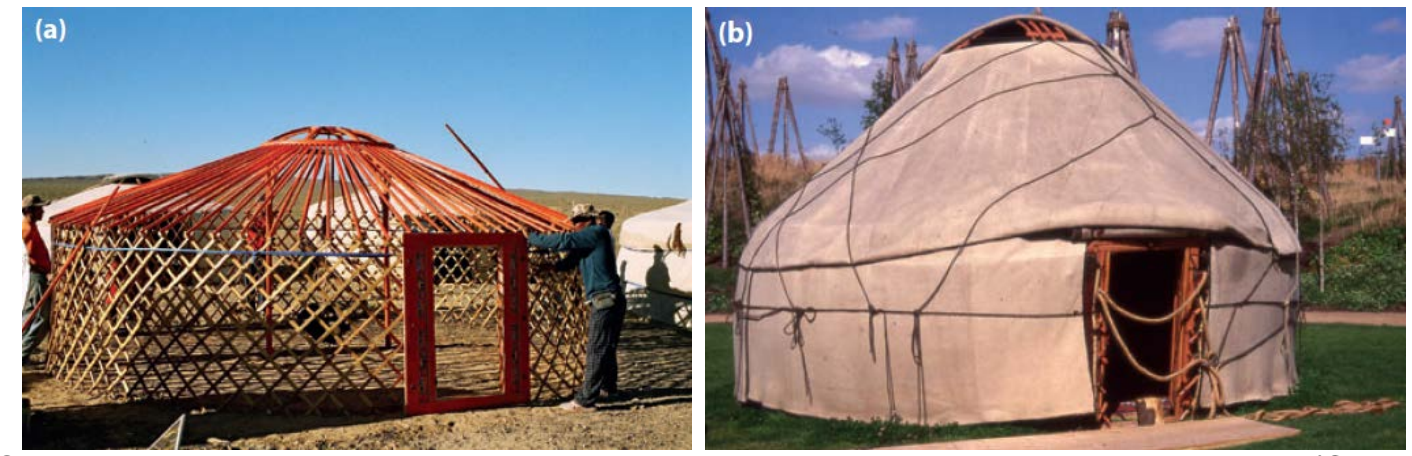

Şekil 1. (a) Moğolistan 'yurt' yapısı tek katlı ızgara kabuk, (b) kaplanmış ızgara kabuk (Chilton ve Tang, 2016, s. 2).

20. yy'ın ortalarından sonra (1960'lı yıllarda) ilk defa ahşap ızgara kabuk sistemlerin gelişimi görülmektedir. Rus inşaat mühendisi Vladimir Shukhov (1853-1939), 1897'de Vyksa'da dünyanın ilk hafif çelik ızgara kabuklarını inşa etmesine rağmen, Alman mimar Frei Otto (1925-2015), modern ahşap ızgara kabukların temsilcisi sayılmaktadır (Haddal Mork vd., 2016). 1964 yılında Frei Otto önderliğinde Stuttgart Teknik Üniversitesi'nde Hafif Yapılar Enstitüsü kurulmuş ve süregelen yıllarda birçok ahşap ızgara kabuk yapı tasarlanmıştır (Songel, 2020, s. 233).

Ahşap ızgara kabuklar, ayrık yüzey özelliğinde, ince, hafif, uzun ve eğri çubuklardan oluşan, eşit yayılı yükler altında basınç ve çekme gerilmelerini karşılayan, düz zeminde kurulumu ile bağlantıları yapıldıktan sonra farklı yapım yöntemleriyle itilerek veya çekilerek son biçimine getirilen taşıyıcı sistemlerdir (Şekil 2) (Collins ve Cosgrove, 2016; Türkçü, 2017, s. 167) 

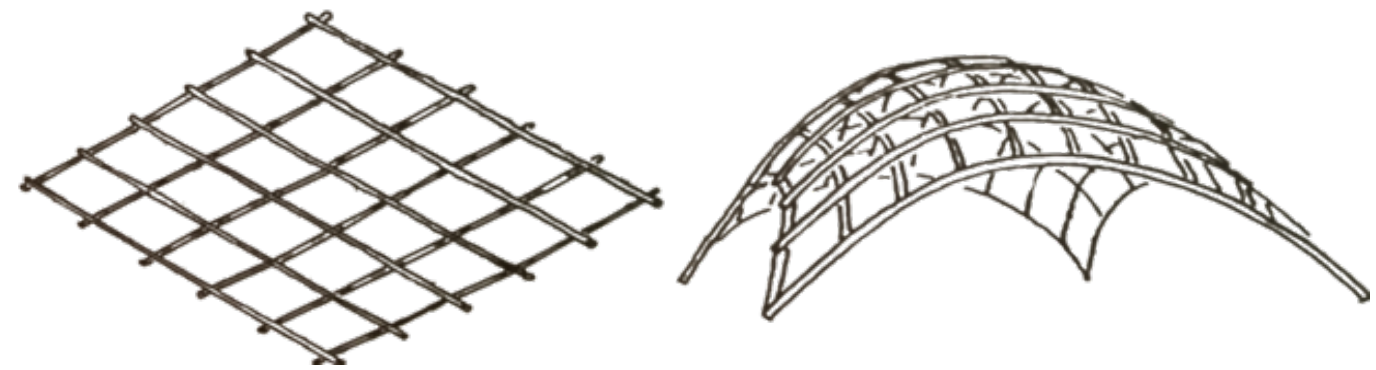

Şekil 2. Dörtgen (kare) planlı ızgara kabuk formunun oluşumu (Türkçü, 2017, s. 167).

Bu sistemler, ayrık bileşenlerden kurulan eğri yüzeyleri ve ızgara geometrileriyle çubuk ağı kubbeleri ile çok büyük benzerlikler göstermektedirler. Statik çalışma yönünden ise hem kabuk sistemlerden hem de uzay kafes sistemlerden farklıdırlar. Uzay kafes sistemler ile ızgara kabukların statik çalışma yönünden farkı mafsallı düğüm noktalarıdır. Uzay kafes sistemlerde yükler mafsallı düğüm noktalarında çekme ve basınç gerilmeleri ile karşılanırken, ızgara kabuklarda düğüm noktaları yalnızca montaj sürecinde gevşek bir mafsal gibi davranmaktadır. Kabuklar her yönden gelen yükleri çekme, basınç ve kayma gerilmeleri ile karşılarken, ızgara kabuklar, sadece çubukların eksenleri doğrultusunda etki eden yükleri karşılar. Sürekli ince kabuklarda serbest bölgelerde basınç, çekme ve kayma eğilimine meyilli bölgelerde eğilme meydana gelirken, ızgara kabuklarda eşit yayılı yükler altında basınç, sonra çekme oluşur ve kayma gerilmeleri karşılanamaz. Bu sebeple ızgara kabuklarda ek önlemlerin alınması gerekir. Bu önlemler, tabakaların arasına kayma blokları yerleştirme, rüzgar yüklerine karşı bağlantılar yapma, belirli düğüm noktalarından çapraz kablo geçirme veya taşıyıcı iskeletin üzerinde hafif fakat rijit kaplama plakalarının kullanımı şeklinde sıralanmaktadır (Şekil 3) (Türkçü, 2017, s. 167-168; Naicu, 2012, s. 22-23).

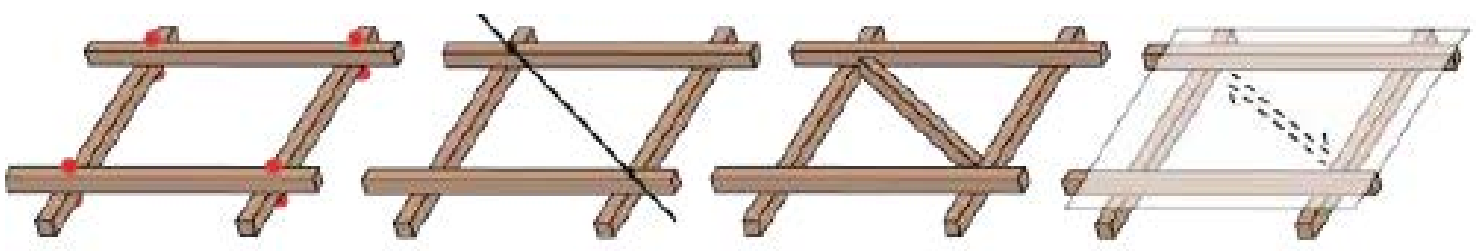

Şekil 3: a) Rijit birleşimler b) çapraz çelik kablolar c) rijit (ahşap) çapraz destek d) rijit kaplama Şekil 3. Bağlantı destek elemanları (Naicu, 2012, s. 22).

Izgara kabukların düğüm noktalarındaki çizgisel ahşap elemanlar, yük durumuna göre tek tabakalı (her iki doğrultuda birer) veya iki tabakalı (her iki yönde ikişer) yapılarak taşıma kapasitesi artırılmaktadır (Şekil 4).

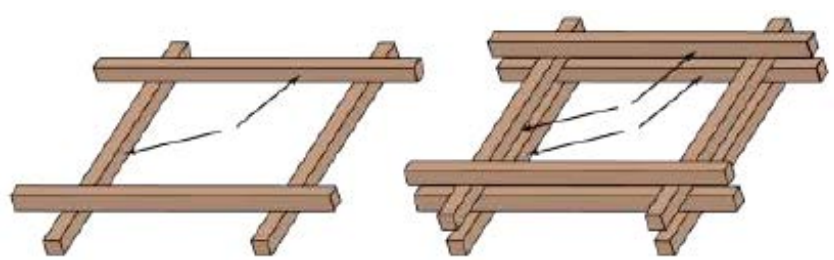

Şekil 4. Tek tabakalı ve çift tabakalı ahşap ızgara kabuk elemanları (Naicu, 2012, s. 22).

Çok sayıda düğüm noktasına sahip olan ızgara kabuklardan, tek tabakalı ızgaralarda düğüm noktaları karmaşık değildir fakat çift tabakalı sistemlerde bu detay karmaşık bir hale gelmektedir (Collins ve Cosgrove, 2016). Ahşap ızgara kabuklarda, ahşap elemanların birleşiminde farklı yöntemler kullanılmaktadır. Bu sistemlerde ahşap 
elemanların birleşiminde tutkal kullanılmamakta; elemanlar bir araya getirilerek metal plakalar, çivi, cıvata ile bağlanmaktadır.

Çok sayıda düğüm noktasına sahip olan ahşap ızgara kabuklarda, düğüm noktasından geçen kuvvet doğrultularına göre 2 veya 3 yönlü ızgaralar tanımı yapılır (Tablo 1). 2 yönlü ızgaralar, dörtgen modüllerden (kare, dikdörtgen ve eşkenar dörtgen planlı), 3 yönlü ızgaralar ise üçgen modüllerden (dik veya eşkenar üçgen planlı) oluşturulur. Dörtgen modüllü ızgaralar köşegenleriyle bölündüğünde 3 yönlü ızgaralara dönüşürler. 2 yönlü ızgaralar, modül geometrileri sebebiyle kolay şekil değiştirebildikleri için imalat, yapım ve montaj aşamasında daha avantajlıdırlar (Türkçü, 2017, s. 171).

Modül geometrisi belirlenen ızgaralarda, yapım yöntemi ve kullanılan elemanların sürekli, parçalı olma durumuna göre farklı ızgara düzenleri ortaya çıkmaktadır. Bu ızgara düzenleri (Larsson, 2018, s. 71-76); Zollinger, geçmeli, dokuma, parçalı, karma, kademeli parçalı olmak üzere sıralanmaktadır.

1920'lerde Alman mimar Friedrich Zollinger tarafından geliştirilen Zollinger ızgara düzeninde, her ızgara çizgisi bir adım kaydırılmakta ve her düğüm noktasında bir ahşap eleman devam ederken diğer iki ahşap eleman sonlanmaktadır. Toskana Therma Bad Orb yapısında kullanılan bu ızgara düzeni, küçük ölçekli elemanlardan oluşması sebebiyle kapsamlı bir iskele intiyacı oluşturmaktadır. Geçmeli ızgara düzeni, yarım bindirmeli (geçmeli) birleşim noktalarından oluşan ve sürekli elemanlar aracılığıyla eksenel kuvvetlerin aktarılmasına izin veren bir sistemdir. La Seine Musicale yapısında kullanılan bu ızgara düzeninde, sürekli elemanlar sebebiyle iskele kullanımı intiyacı azalırken; düğüm noktalarının yapısal dayanımına bağlı olarak bu intiyaç değişkenlik göstermektedir. Dokuma ızgara düzeni, her doğrultuda iki eleman kullanılarak çift tabakalı biçimde düzenlenen ve tabakalar arasında kayma blokları kullanılan bir ızgara düzenidir. Mannheim Multihalle, Weald and Downland, Savill Garden gibi elastik ahşap ızgara kabuklarda yaygın olarak kullanılan bu düzene, Centre Pompidou Metz gibi rijit ahşap ızgara kabuklarda da rastlanabilmektedir. Parçalı ızgara düzeni, süreksiz elemanlardan oluşmaktadır. Kısa elemanların birleşiminden oluşan sistemin dezavantajı, dört elemanın bağlantısını içeren çok sayıda karmaşık düğüm noktasına sahip olmasıdır. Herbert Art Gallery ve Canary Wharf Railway Station bu ızgara düzeninin kullanılığı örneklerdendir. Karma sistem, bir yönde uzun, sürekli elemanların ve diğer yönde kısa, süreksiz elemanların birleşiminden oluşan bir ızgara düzenidir. Parçalı ızgara düzenine kıyasla daha basit bir iskele ile oluşturulabilmektedir. Kademeli parçalı ızgara düzeni, karma sistemin özel bir durumu olarak her iki yönde daha uzun elemanlardan oluşmaktadır. Bu ızgara düzeninin olumlu yönlerinden biri iskele ihtiyacının az olmasıdır (Larsson, 2018, s. 71-76). Farklı modül geometrisi ve ızgara düzeni kombinasyonları ile tek eğrilikli, çift eğrilikli ve serbest biçimli ahşap Izgara kabuklar oluşturulabilmektedir (Tablo 1). 
Tablo1. Yapı geometrisini oluşturan birimler (Larsson, 2018, s. 71-76; Türkçü, 2017, s. 170; Charest vd., 2019).

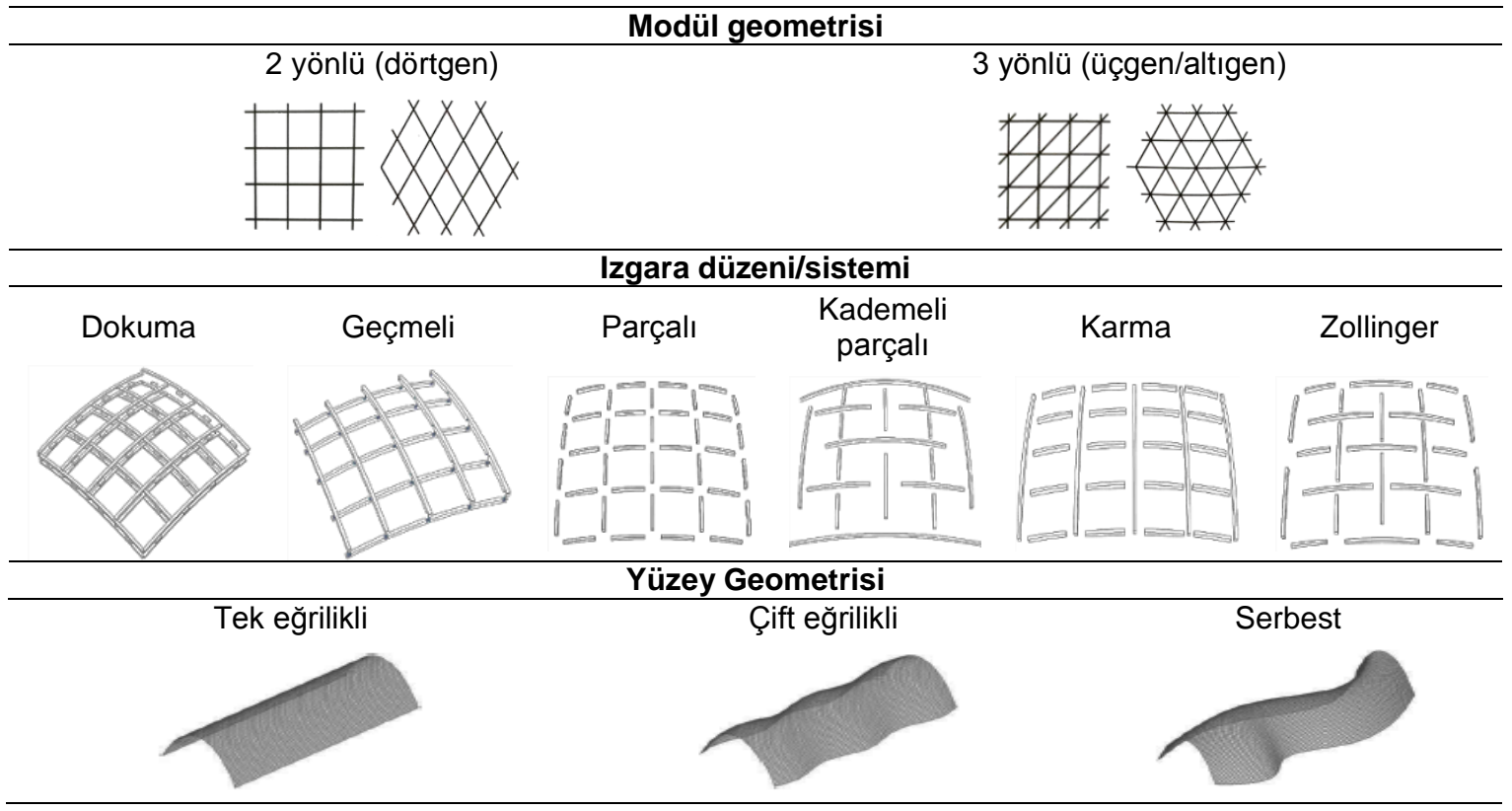

Ahşap ızgara kabuklar, basit bir geometriyle oluşturulan yapılar olabileceği gibi, birçok temel geometrik biçimin bir araya gelerek oluşturduğu karmaşık geometrili yapılar da olabilmektedir. Bu yapıların tasarımındaki en önemli sorunlardan biri, yapının geometrik özelliklerine karar vermektir (Avelino, Baverel ve Lebée, 2019, s. 189-190). Form bulma süreci farklı disiplinlerin tasarım kararlarının sentezini içeren kritik bir süreçtir. Ahşap ızgara kabukların tasarımında kullanılan form bulma yöntemleri; basit form bulma yöntemleri (deneysel yaklaşımlar) ve hesaplamalı form bulma yöntemleri (matematiksel/nümerik yaklaşımlar) olmak üzere sınıflandırılabilir.

Deneysel yaklaşımlar, tasarımcıların serbest biçimli karmaşık yapıları sonlu elemanlar programları kullanmadan incelemelerini sağlamıştır. Bilgisayar teknolojisinin gelişimiyle günümüz ızgara kabuklarının tasarımı ve biçimi mimarların kontrolünde fakat tamamen bilgisayar aracılığıyla yapılmaktadır. Matematiksel yaklaşımlar, deneysel biçim belirlemede maket uygulama süreçlerinde ortaya çıkan sorunları azaltmakla birlikte tamamen ortadan kaldırmamaktadır. Teknolojinin gelişimi, parametrik tasarım olanağı sağlayan programların (CATIA, Rhino, Grasshopper 3D, Kangaroo Physics, Karamba 3D vb.) yaygınlaşması da bu yöntemle ön tasarım aşamasında biçim belirlemeyi kolaylaştırmış ve ızgara kabukların gelişiminde yeni bir dönemi başlatmıştır (Haddal Mork vd., 2016; Türkçü, 2017, s. 170). Aynı zamanda, hesaplama araçlarının kullanımı fiziksel modellerin oluşturulmasına kıyasla form bulma sürecini önemli derecede kısaltabilmektedir (Ağırbaş, 2019, s. 31; Tang vd., 2013, s. 5).

Günümüzde ahşap ızgara kabukların üretiminde bilgisayarla sayısal olarak kontrol edilen (CNC) makineler kullanılmaktadır. Robotic Timber Construction (RTC), robotik montaj prosedürlerini ve standart dışı ahşap yapıların gelişmiş dijital tasarımını birleştirirken, dijital tasarım verilerini doğrudan montaj işlemlerine aktarma özelliğine sahiptir. Dijital tasarım ve üretimin bir arada kullanılması, serbest biçimli karmaşık ahşap yapılarda kullanılan elemanların prefabrike hale getirilmesini mümkün kılmaktadır (Willmann vd., 2016). 
Ahşap ızgara kabuklarla ilgili elde edilen bilgilere göre; bu strüktürlerin olumlu ve olumsuz yönleri aşağıda belirtilmektedir.

Ahşap ızgara kabuk strüktürlerin olumlu yönleri aşağıda sıralanmaktadır:

- Geçtikleri açıklıklara oranla sahip oldukları ince kesitler nedeniyle estetik görünümleri,

- Büyük alanları kaplamalarına rağmen boşluklu yapıları ve ahşap malzemenin kullanımı sebebiyle diğer taşıyıcı sistemlere (betonarme ve kâgir kabuk) göre daha hafif olmaları (Tang vd., 2013, s. 5; Liuti ve Pugnale, 2015, s. 1)

- Izgara kabuk yapıların, minimum malzeme ile büyük mesafeleri geçmekte etkili sistemler olması (Charest, Shepherd, vd., 2019, s. 2),

- Yapısal verimlilik sağlamaları ve geçtikleri açıklığa oranla kullandıkları malzeme miktarına göre ekonomik olmaları (Fritzsche, 2013, s. 2),

- Izgara formu sebebiyle yapının dış ortamla ilişkisinin kesilmemesi, şeffaflık sağlanabilmesi, günışığından faydalanılabilmesi,

- Diğer yapı malzemeleriyle inşaya oranla oldukça hızlı olması ve kurulum sırasında, ek işlemler gerektirmediğinden maliyet açısından da uygun olması,

- Ahşap yapı malzemesiyle oluşturulan bu sistemlerin ekolojik olması,

- Küçük boyutlardaki ahşap elemanlar kayma blokları gibi değerlendirilebilirken atığın minimuma inmesi (Collins ve Cosgrove, 2016),

- Izgara kabukların elemanları arasındaki boşlukların aydınlatma ve tesisat için avantaj sağlayabilmesi (Paoli, 2007, s. 19),

- İç mekân tasarımında taşıyıcıların gerekmemesi sebebiyle sergi, müze gibi alanlar için avantajlı yapılar olması.

- Ahşap ızgara kabuk strüktürlerin olumsuz yönleri ise aşağıdaki gibi sıralanabilir:

- Her ahşap ızgara kabuğun kendine özgü formu sebebiyle tasarım, yapım aşamalarında uzmanlık gerektirmesi (Yılmaz, 2011, s. 106),

- Bağlantıların yük şartlarına göre doğru yapılması gerekliliği, aksi durumda ahşap elemanlarda kırılmaların gözlenebilmesi,

- İşçilik maliyetlerinin fazla olması,

- Ortogonal bir malzeme olan ahşabın, bağlantı tasarımındaki zorlukların Izgaraları olumsuz etkilemesi,

- Yapısal analizdeki ve form bulmadaki zorluklar,

- Kabuğun kaplama malzemesiyle örtülmesinin montaj sürecinin en uzun aşaması olması (Paoli, 2007, s. 19),

- Karmaşık tasarım süreci (Haddal Mork vd., 2016), mühendislik açısından yapısal hesaplamaların zorluğu, bilgi ve veri eksikliği (Harris, Romer, Kelly ve Johnson, 2003), üretim ve yapım sorunları (Liuti ve Pugnale, 2015, s. 3) nedeniyle az sayıda ahşap ızgara kabuk yapı örneğinin bulunması (Ghiyasinasab, Lehoux ve Ménard, 2017, s. 2-13).

\subsection{Ahşap ızgara kabukların sınıflandırılması}

Ahşap ızgara kabukların sahip olduğu özelliklere göre; elastik, rijit, tek tabakalı, çift tabakalı, 2 yönlü, 3 yönlü gibi farklı ön isimlerle ele alındığı görülmektedir. Çalışmada ahşap ızgara kabukların tasarım ve uygulama süreçlerindeki farklılıklar sonucu ortaya çıkan özelliklerine göre bir sınıflandırma oluşturulmuştur. Buna göre ahşap ızgara kabuklar; strüktürel davranışlarına, tabaka sayısına, ızgara düzenine, formlarına, form bulma yöntemlerine ve modül geometrisine göre sınıflandırılmıştır (Şekil 5).

Ahşap ızgara kabuklar strüktürel davranışlarına göre; aktif bükülmüş/elastik ve rijit ızgaralar olmak üzere ikiye ayrılmaktadır (Collins ve Cosgrove, 2016). Aktif bükme 
terimi; ızgara kabukların nihai forma ulaşması için yapıyı oluşturan ana elemanların yapım aşamasında bükülerek deforme edilmesi olarak açıklanmaktadır. Farklı bir ifadeyle, montaj sırasında Izgara geometrisinde deformasyonlara izin veren kabuklar elastik olarak kabul edilirken, prefabrike elemanlardan oluşan ve farklı montaj teknikleri gerektiren sistemler rijit olarak ele alınmaktadır (Charest, Potvin, Demers ve Ménard, 2019).

Yapılan sınıflandırmadaki nitelikler, çalışmada elastik ve rijit ahşap ızgara kabuk başlıkları altında incelenmektedir.

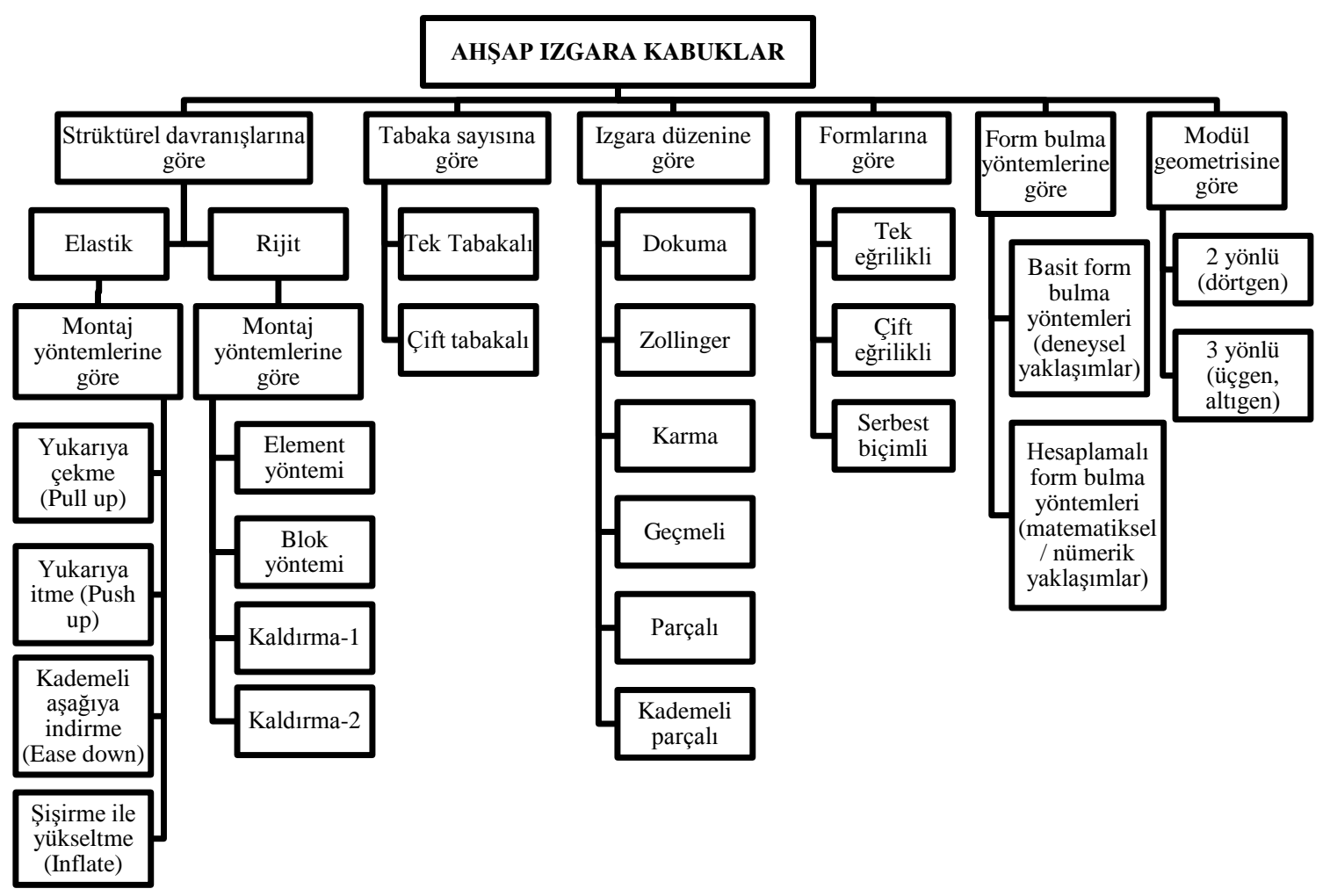

Şekil 5. Ahşap ızgara kabukların sınıflandırııması.

\subsubsection{Elastik ahşap Izgara kabuklar}

Elastik ahşap ızgara kabuklar, sürekli elemanlardan oluşan, genellikle 2 yönlü (dörtgen modüllü) olarak düzenlenen ve dokuma ızgara düzeninin kullanıldığı taşıyıcı sistemlerdir. Multihalle Mannheim, The Weald and Downland Museum, The Savill Garden yapıları elastik ahşap ızgara kabukların en önemli örneklerindendir (Şekil 6) (D'Amico, 2015, s. 24). 


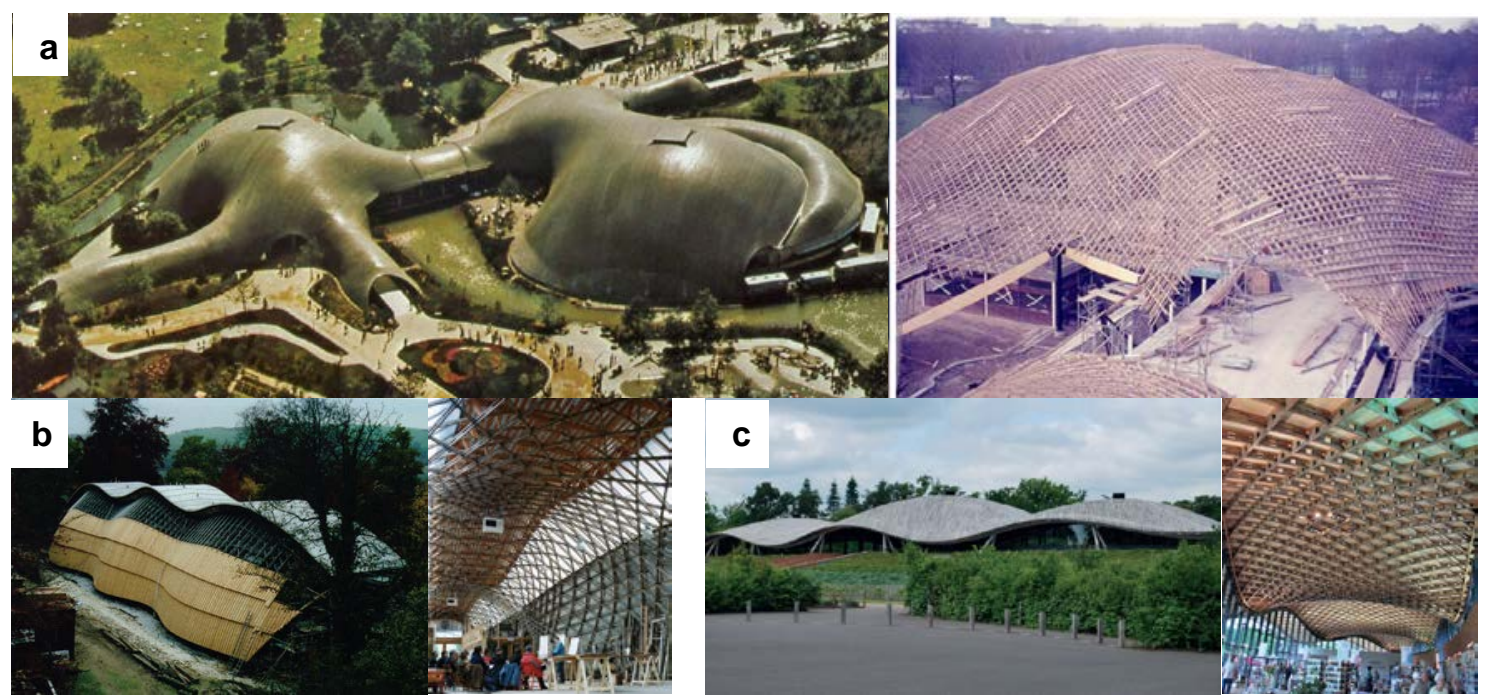

Şekil 6. (a) Multihalle Mannheim (Liddell, 2015, s. 39), (b) The Weald and Downland Museum,

(c) The Savill Garden (Chilton ve Tang, 2016, s. 58, 62).

Elastik ızgara kabukların tasarımı açısından en önemli özelliklerinden biri, montaj şemasıdır. Bu sistemlerin yapımı kablo sistemlerin yapımına benzer; genellikle yere düz olarak yatırılan ince en kesitli çubuklar yukarıya kaldırılıp belirli noktalardan itilip çekilerek son biçimine getirilir. Montaj süreci kablo ağlarıyla benzerlik gösteren elastik ahşap ızgara kabuklarda, iki doğrultuda birbiri üzerine yerleştirilen taşıyıcı sistem bileşenleri, düğüm noktalarındaki bulonlar yerlerine geçirilerek tam sıkılmadan bırakıldığı için hareket edebilme özelliklerini kaybetmezler ve böylece eğri yüzeylerin oluşmasına (dörtgen/kare modüllerin baklava dilimlerine dönüşümü) izin verirler. Elastik Izgara kabuklar düz bir zeminde düzenlendikten sonra istenilen serbest biçime ulaşmak için dört yöntem (Şekil 7) bulunmaktadır:

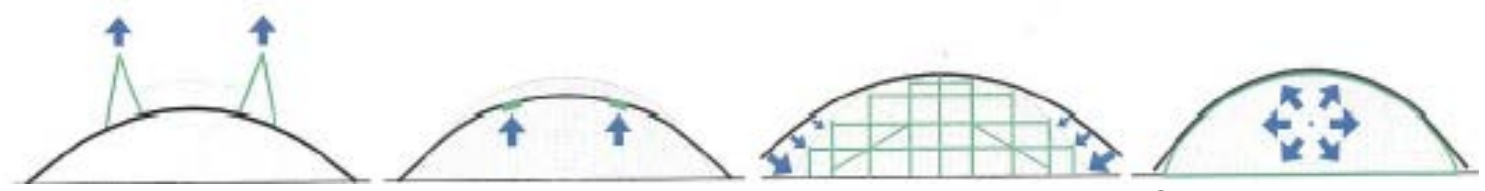

1) Yukarıya çekme 2) Yukarıya itme 3 ) Kademeli aşağıya indirme 4) Şişirme ile yükseltme Şekil 7. Dört farklı montaj yöntemi (Quinn ve Gengnagel, 2015; Quinn ve Gengnagel, 2014).

Yukarıya çekme (Lift/pull up) yöntemi, ızgarayı belirli düğüm noktalarından vinçler ve kablolar yardımıyla yukarı çekmektir. Bu yöntem hızlı olması sebebiyle avantajıdır fakat yapının büyüklüğüne bağlı olarak gereken vinç sayısı sebebiyle ekonomik olmamaktadır. Frei Otto tarafından 1962'de Essen'de inşa edilen ilk elastik ahşap ızgara kabuk (Alman Yapı Sergisi DEUBAU), tek bir mobil vinç ile kaldırılmış ve ahşap dikmelerle destelenmiştir. Yukarıya itme (Push up) yöntemi, önceden belirlenen noktalara kurulmuş krikolar ve iskeleler yardımıyla bağlantı elemanları tam olarak sıkılmamış ızgaranın alttan itilmesidir. Multihalle Mannheim kabuğu, maliyeti düşürmek için bu yöntem ile inşa edilmiştir. Zemin seviyesinde montajı yapılan ızgara, $\mathrm{H}$ formundaki yükü yayan kirişlere bağlı iskeleler kullanılarak, forkliftler yardımıyla yukarı doğru itilmiştir (Şekil 8). Her iki teknik de yerçekimi kuvvetlerine karşı hareketleri içermesi sebebiyle ek müdahaleler gerektirmektedir. Uygulamada iki teknik arasındaki seçim; kabuğun büyüklüğü, kaldırma noktası olarak belirlenen düğüm sayısı ve montajın öngörülen süresi (gerekli ekipmanın tedarik süresi) gibi değişkenlere bağlıdır (Fernandes, Kirkegaard ve Branco, 2016; Quinn ve Gengnagel, 2014). 

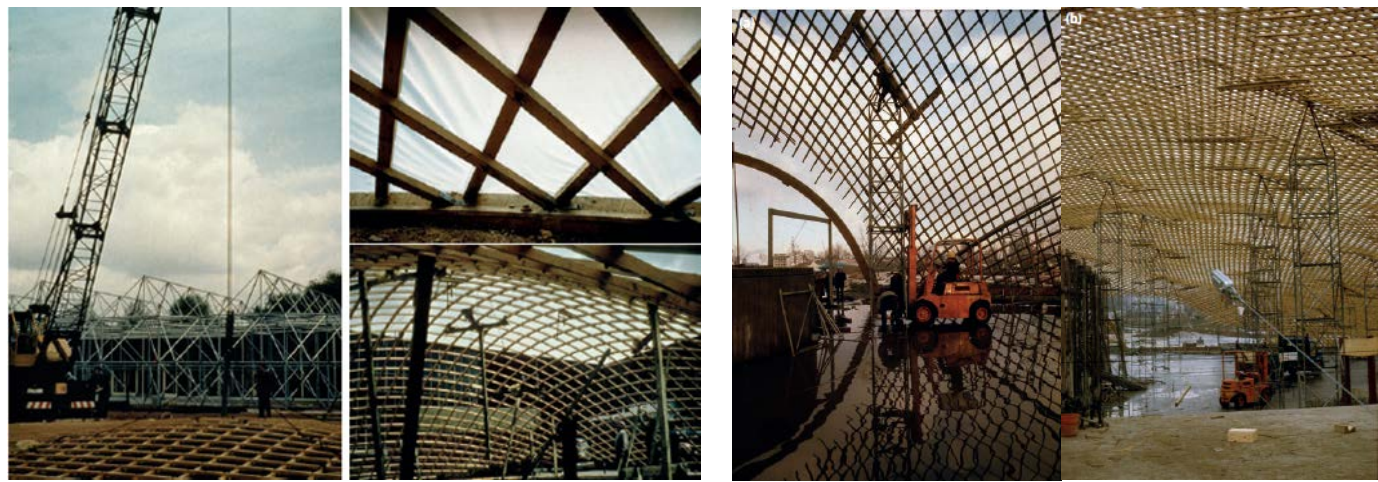

Şekil 8. Yukarıya çekme yöntemi; Essen Pavilion (Alman Yapı Sergisi DEUBAU) (Chilton ve Tang, 2016, s. 18), Yukarıya itme yöntemi; Multihalle Mannheim forkliftlerle itilen Izgara ve $H$ şeklinde kuvvet yayıcı kirişler (Chilton ve Tang, 2016, s. 34).

Kademeli aşağıya indirme (Ease down) yönteminin avantajı, yerçekimine karşı hareket etmek yerine, bu güçten yararlanmasıdır. Yöntem, zeminden belirli bir yükseklikte iskele üzerinde düzenlenen ahşap ızgaranın kademeli olarak kendi ağırlığı altında kontrollü bir şekilde eğrisel formun oluşumuna olanak sağlamaktadır. İskele üzerinde kurulan ahşap ızgara, krikolar aracılığıyla itilip çekilerek nihai forma ulaştırımaktadır (Şekil 9). Izgara kabuğun alt kısmında şişirilen pnömatik yastıklarla kuvvet uygulanan şişirme ile yükseltme (Inflate) yöntemi, itme kuvvetini düğümler arasında eşit şekilde dağıtmak ve montajın neden olduğu bölgesel gerilmeleri en aza indirmek için etkili bir yöntemdir (Şekil 10) (Fernandes vd., 2016; Quinn ve Gengnagel, 2014).
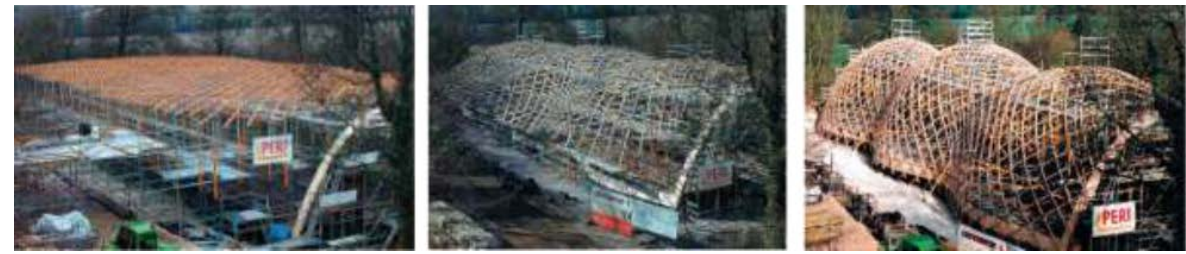

Şekil 9. Kademeli aşağıya indirme yöntemi; Weald and Downland ızgara kabuğu (Harris, Kelly, ve Dickson, 2003, s. 32).

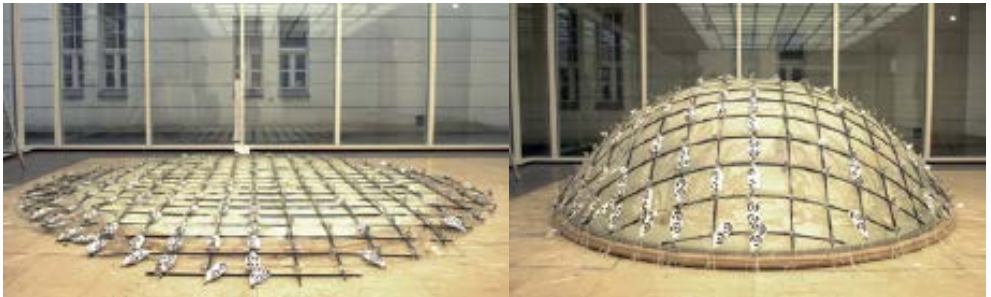

Şekil 10. Şişirme ile yükseltme yöntemi (Quinn, Gengnagel ve Williams, 2015).

Ahşap ızgara kabukların yapım yöntemleri; arazinin büyüklüğü, ulaşım kolaylığı, belirlenen bütçe, çalışma güvenliği, hava şartları ile sistemlerin türü ve büyüklüğüyle ilişkilidir ve bu şartlar göz önünde bulundurularak uygulanır (Vardar Öz, 2012, s. 10).

Elastik ahşap ızgara kabuklar basınç kuvvetleri altında kesme kuvvetlerine dayanmalıdır. Düğüm bağlantıları merkez noktası çevresinde ve dış katmanların iç katmanlara paralel şekilde kaymasına izin verecek şekilde düzenlenmelidir (Şekil 11 (a)) (Collins ve Cosgrove, 2016). İlk yapılarda uygulanan çözüm, gerekli hareketi sağlayacak olan üstteki iki tabakada oluklu delikler bırakarak yapılmıştır (Şekil 11 (a)). Nihai form elde edildikten sonra, bağlantı elemanı olan cıvatalar sıkılmaktadır. İlerleyen yıllarda yeni uygulamalarda (Weald and Downland), düğüm noktalarındaki tabakaları 
birbirine bağlayan 4 cıvatalı çelik plakalar geliştirilmiştir (Şekil 11 (b)). Bu bağlantı elemanının patenti alınarak birçok ahşap ızgara kabuk yapısının düğüm noktalarında kullanılmıştır (Naicu, 2012, s. 24).

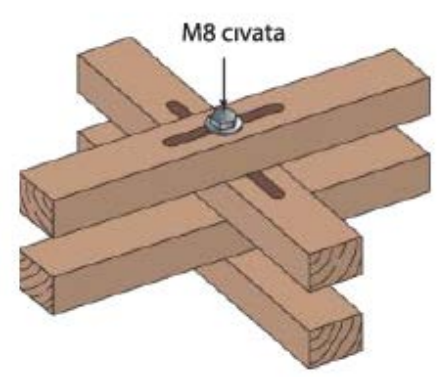

(a)

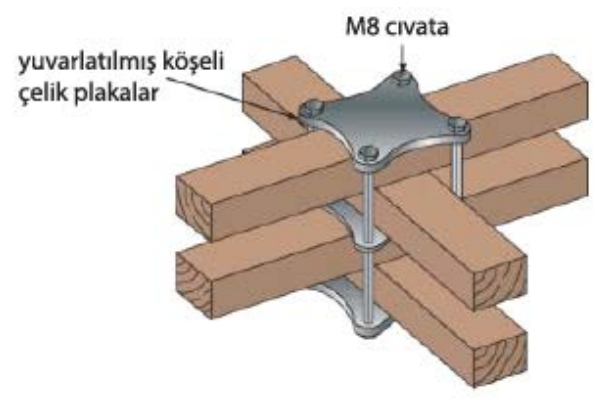

(b)

Şekil 11. Farklı düğüm noktalarında kullanılan elemanlar (Harris vd., 2003, s. 31-32; Naicu, 2012, s. 24)

Elastik ahşap ızgara kabuklarda bağlantı detaylarının tarihsel gelişimi Şekil 12'de sıralanmıştır. Basitten karmaşığa doğru bir sıralamaya sahip olan bağlantı detayları bilgisayar teknolojileriyle paralel olarak gelişme göstermektedir. Tek tabakalı ahşap ızgara kabukların ilk örneklerinden biri olan The Earth Center yapısında paslanmaz çelik cıvataların kullanıldığı rijit birleşimler, düğüm noktalarının en basit tasarımını temsil etmektedir. Bu birleşim küçük ölçekli ve çok sayıda düğüm noktasına sahip olmayan ızgara kabuklarda uygulanmaktadır. Multihalle Mannheim ızgara kabuğun bağlantı detayında iç tabakadaki delikler, düğüm noktasının eleman boyunca aynı noktada kalmasını sağlarken, dış tabakadaki oluklu delikler, bu elemanların kaymasına izin vermektedir. Elemanlara oluklu deliklerin açılması zaman alıcı bir işlem olmakla birlikte, elemanların ve yapının dayanımını da azaltmaktadır (Happold ve Liddel, 1975, s. 124; Paoli, 2007, s. 41). Weald and Downland ızgara kabuğunda geliştirilen yeni yöntem bu soruna çözüm getirmekle beraber montaj sırasında kırılmaların minimum seviyede olmasını sağlamıştır. The Chiddingstone ızgara kabuğunda, Weald and Downland bağlantılarından uyarlanarak geliştirilen çelik braketler, hem güçlendirme elemanı olan çelik gergi kablolarını $(4 \mathrm{~mm})$ hem de cam kaplamayı bir arada tutmaktadır (Chilton ve Tang, 2016, s. 73). The Japan Pavilion ızgara kabuğunda kağıt borular düğüm noktalarında polyester dokuma bant ile bağlanmıştır (Chilton ve Tang, 2016, s. 47) (Şekil 12).

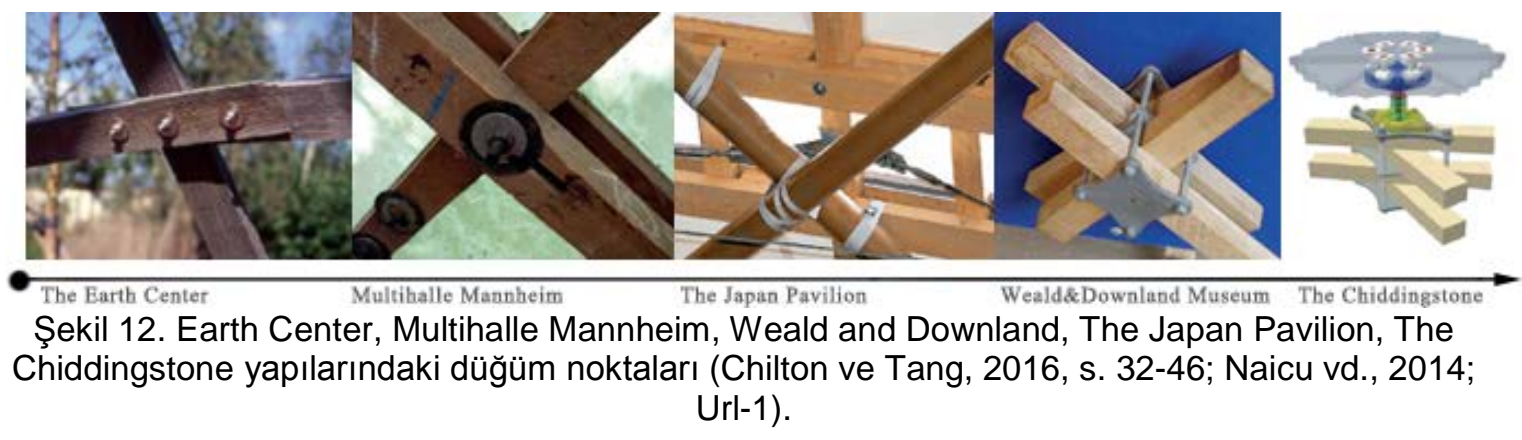

\subsubsection{Rijit ahşap Izgara kabuklar}

Rijit ahşap ızgara kabuklar genellikle 3 yönlü (üçgen modüllü) düzenlenen ve montaj aşamasında deformasyona izin vermeyen prefabrike elemanlardan oluşur (Naicu vd., 2014). Centre Pompidou Metz, Haesley Nine Bridges gibi günümüze yakın tarihlerde inşa edilmiş yapılar rijit ahşap ızgara kabuk örneklerindendir (Şekil 13). Rijit ahşap 
ızgara kabuklarda genellikle Zollinger, geçmeli, parçalı, karma ve kademeli parçalı ızgara düzenleri kullanılmaktadır (Larsson, 2018).
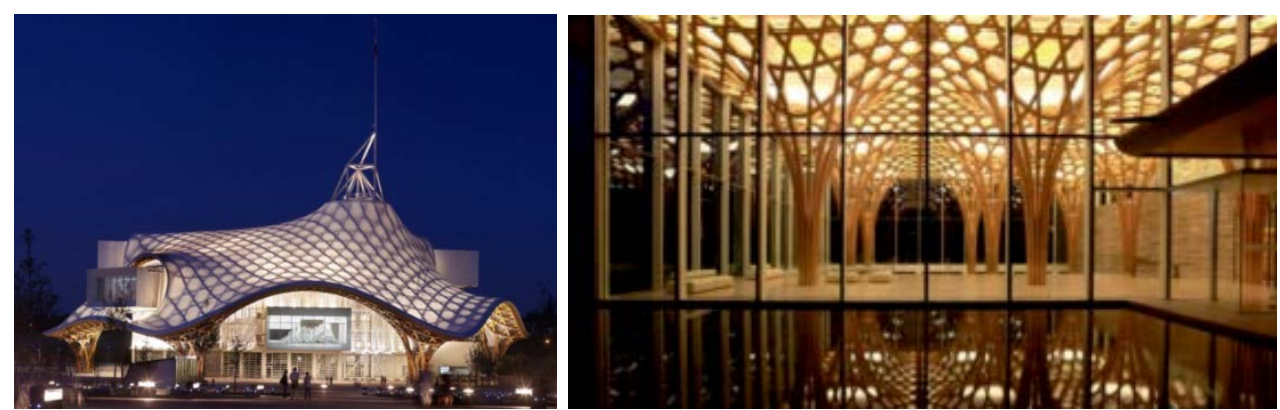

Şekil 13. Pompidou Center dış görünümü (Url-2), Haesley Nine Bridges Golf Kulübü (Url-3).

Rijit ahşap ızgara kabuklar, uzay kafes sistemlerin yapım yöntemlerine benzer şekilde, fabrikada delinmiş ve boyutlandırılmış elemanların sahada doğrudan birleştirilmesiyle oluşturulmaktadır. Uzay kafes sistemlerin yapımına ait bu yöntemler; element, blok, kaldırma 1 ve kaldırma 2 olarak tanımlanmaktadır. Element yöntemi, zemin seviyesinde oluşturulan ve boyutlarına göre ayrılan birimlerin, sistem üzerindeki koordinatlarına uygun olarak vinç ile oturtulup son birleştirme işlemlerinin yapılmasıdır. Blok yöntemi, zeminde montajı biten elemanların, bloklar halinde boyutlarına göre sınıflandırılarak, büyük vinç ve hidrolik krikolar yardımıyla kaldırılarak uygun yere yerleştirilmesidir. Kaldırma 1 yönteminde montajı biten elemanlar, merkezde bir kule yardımıyla veya sistemin iki tarafında makaralı hidrolik sistemlerle kaldırılarak son montajı zeminden yukarıda yapılmaktadır. Kaldırma 2 yönteminde ise, zemin seviyesinde montajı ve son birleşimleri yapılan elemanlar, merkezde bir kule yardımıyla veya sistemin iki tarafından makaralı hidrolik sistemlerle kaldırılarak yerleştirilmektedir (Demirbaş ve Girgin, 2019, s. 16; Vardar Öz, 2012, s. 10-13). Prefabrike elemanların veya birimlerin numaralandırılarak belirlenmesi sahada yapımı kolaylaştırmakta ve yapım süresini kısaltmaktadır.

Toskana Thermal Springs, Pompidou Metz, Haesley Nine Bridges, gibi rijit Izgara kabuklar, vinç ve krikolar yardımıyla geçici iskele ve kalıplar kullanılarak inşa edilmiştir (Şekil 14).
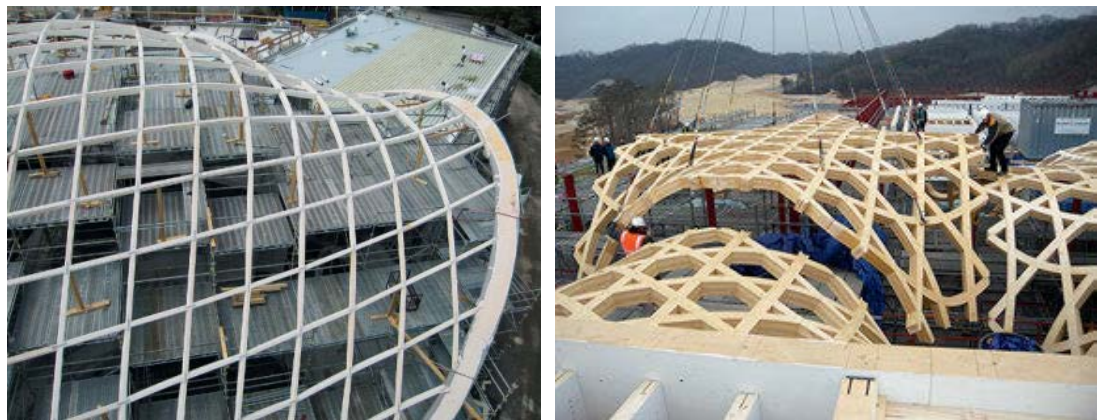

Şekil 14. Rijit ahşap ızgara kabukların montajı; Toskana Thermal Bad Orb, Haesley Nine Bridges (Jeska, Hascher ve Pascha, 2014, s. 116-165).

Dijital tasarım ve üretim tekniklerinin gelişimiyle rijit ızgara kabukların sayısı artmış ve yapıya özgü farklı bağlantı detayları geliştirilmiştir.

Larsson (2015) çalışmasında, bu yapılarda kullanılan bazı bağlantı detaylarını; basit birleşim, güçlendirilmiş basit birleşim, yarım bindirmeli birleşim, çelik düğüm 1. ve 2. tip olarak sıralamaktadır (Şekil 15). Rijit ahşap ızgara kabuklarda, maliyeti diğer birleşim 
detaylarına oranla daha düşük olan basit birleşim detayı genellikle Zollinger tipinde oluşturulmuş ızgara düzenine sahip yapılarda kullanılmıştır. Sistemin eksenel direncini artıran güçlendirilmiş basit birleşim, kirişlerde daha fazla işleme intiyaç duyması sebebiyle basit birleşimden daha karmaşıktır. Yarım-bindirmeli (geçmeli) birleşim, yüksek mukavemetli, çelik elemanların az miktarda kullanıldığı ekonomik birleşimlerdir. Bu birleşimlerde, çelik bağlantı detaylarının ahşap elemanlarla örtülmesi ve boşlukların dübel, mineral yün, yangın koruma dolguları ile doldurulması gibi basit önlemlerle yangından koruma sağlanmaktadır. Mukavemetin çelik düğümlerle sağlandığı birleşim detayları diğerlerine oranla daha yüksek maliyetli ve karmaşıktır. Yapıya göre her düğümün ayrı tasarlanması ve üretilmesi, açıkta kalan çelik elemanların yangına karşı korunması gerekebilmektedir (Larsson, 2018, s. 77-92). Çelik birleşim detayları, ahşap ızgara kabuğun formuna ve ızgara düzenine göre her yapı için değişkenlik gösterebilmektedir.

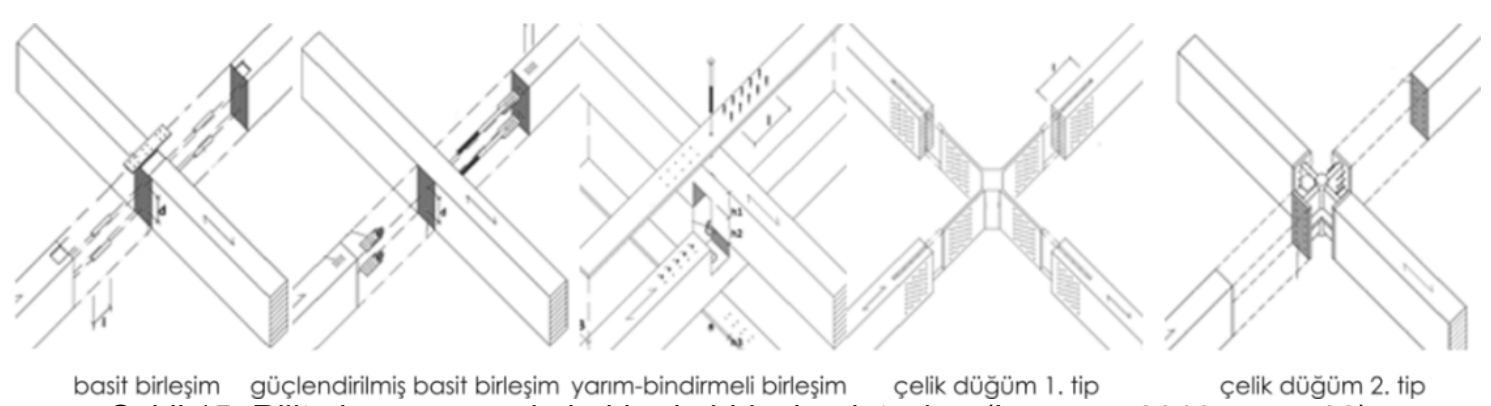

Şekil 15. Rijit ahşap ızgara kabuklarda birleşim detayları (Larsson, 2018, s. 77-92).

\section{Ahşap Izgara Kabuk Örneklerinin İncelenmesi}

İlk ve son ahşap ızgara kabuk örnekleri arasında geçen yaklaşık 50 yıl, yapısal yönden birçok farklılık getirmiştir. Özellikle bilgisayar teknolojilerinin gelişmesiyle, ahşap ızgara kabuk yapıların mimari ve yapısal tasarım sürecinde yenilikler gözlemlenmiştir. Şekil 16 'da incelenen projeler tarihsel olarak sıralanmaktadır.
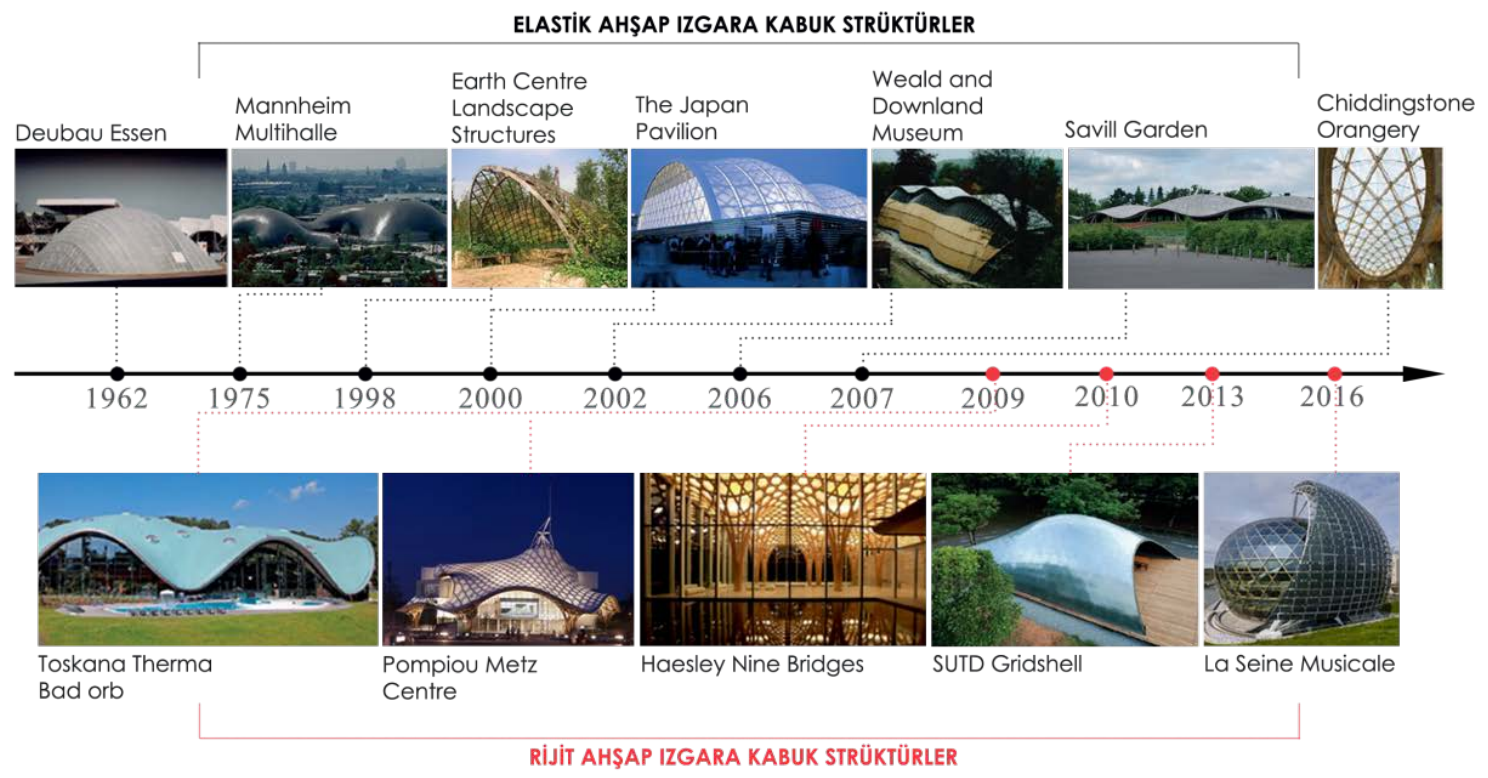

Şekil 16. Çalışmada incelenen ahşap ızgara kabukların zaman çizelgesi.

İnceleme yöntemine göre; yapı ölçeği, kullanılan yapım yöntemleri, bilgisayar teknolojileri, bağlantı detayları, ızgara düzenlerinde gözlenen yenilikler göz önünde 
bulundurulmaktadır. Çalışmada incelenen ahşap ızgara kabuklar, inşa edildiği dönemde bahsedilen özelliklerde yeniliklere öncülük etmiş olan ve ızgara kabukların gelişimini gösteren yapılardır.

Frei Otto tarafından tasarlanan Essen Pavilion (Alman Yapı Sergisi DEUBAU), tek tabakalı ahşap ızgara kabukların ilk örneklerindendir. Ahşap ızgara kabuklara öncü olan bu yapıyla beraber, hafiflik, mimari nitelikler ve prefabrikasyon gibi avantajlar sebebiyle bu alanda daha fazla araştırma yapma potansiyeli olduğu ortaya koyulmuştur. 1975 yılında inşa edilen Multihalle Mannheim, ilk çift tabakalı ve büyük ölçekli ahşap ızgara kabuk örneğidir. Ahşap ızgara kabukların ilk örnekleri Almanya'da üretildikten sonra Earth Center yapısı, Buro Happold tarafından İngiltere'de tasarlanan yapıların ilkidir. Kâğıt tüplerden oluşturulan The Japan Pavilion'un ahşap ızgara kabuk örnekleri arasında yer almasının sebebi takip eden ahşap ızgara kabukların geliştirilmesindeki etkisinden kaynaklanmaktadır. Yapım yönteminde deneysel ve öncü tekniklerin kullanımı, Weald and Downland ızgara kabuğunun yapım sürecinde bu tekniklerin benimsenmesine yol açmıştır. 2002 yılında inşa edilen farklı yapım yöntemlerinin ve bağlantı detaylarının geliştirildiği The Weald and Downland, gelecekteki elastik ahşap ızgara kabuklar için bir öncü sayılmaktadır. The Savill Garden ve The Chiddingstone, ahşap Izgara kabuklardaki geçiş döneminin gelişmiş örneklerindendir. Bu örneklerden sonraki yıllarda inşa edilen Centre Pompidou Metz, Toskana Thermal Bad Orb, Haesley Nine Bridges Golf Resort, SUTD gridshell, Cite Musicale yapıları rijit ahşap ızgara kabukların önemli örneklerinden sayılmaktadır. Günümüze yakın tarihlerdeki rijit ahşap ızgara kabuklarda, gelişmiş üretim teknikleri ve bilgisayar teknolojileri kullanılarak farklı bağlantı detayı ve ızgara sistemlerinin oluşturulduğu görülmektedir. Ahşap ızgara kabuk örneklerine ilişkin bilgiler sistematik bir şekilde Tablo 2 ve Tablo 3'te sunulmuş ve sonuç bölümünde değerlendirilmiştir.

Tablo 2, Quinn ve Gengnagel (2014) çalışmasında yer alan elastik ızgara kabuklara ait tablodan uyarlanmıştır. Yayımlanmış farklı çalışmalardan elastik ahşap ızgara kabuklara ilişkin veriler toplanmıştır. Tablodan bazı yapılar çıkarılarak yerine bu çalışmada incelenen farklı ahşap ızgara kabuk örnekleri eklenmiştir. Ayrıca çalışma kapsamında elastik ve rijit ızgara kabukların karşılaştırılmasına olanak sağlayacak şekilde aynı parametreler kullanılarak Tablo 3 oluşturulmuştur. Rijit ahşap ızgara kabuklara dair veriler toplanarak Tablo 3'te sunulmuştur.

Tasarım ve üretim sürecinin zorlukları (Haddal Mork vd., 2016; Liuti ve Pugnale, 2015) nedeniyle elastik ahşap ızgara kabuklar 2000'li yılların başlarından itibaren yerini rijit ahşap ızgara kabuklara bırakmıştır. Bu yıllardan sonra küçük ölçekli veya deneysel çalışmalarda elastik ahşap ızgara kabuklar görülmeye devam etse de gelişen teknolojinin getirdiği avantajlar sayesinde rijit ızgara kabukların günümüzde sayıca daha fazla olduğu görülmektedir.

Tablo 2'de incelenen elastik ahşap ızgara kabukların tasarım ve üretiminin sınırlı bir alanda (Almanya ve İngiltere) yoğunlaştığı görülmektedir. Elastik ahşap ızgara kabuklarda; sürdürülebilir endüstriyel ormanlardan elde edilen ve yerel kaynaklardan (çam, ladin, meşe, karaçam) üretilmiş, geleneksel yöntemler (parmak-geçme, pahlı birleşim) kullanılarak saha dışında birleştirilmiş, küçük kesitli ahşap çıtalar kullanılmıştır. Düğüm noktaları basit detaylandırılmış; bulon ile mafsallı birleşim veya Weald and Downland ızgara kabuğu için üretilerek patenti alınan ve daha sonra diğer yapılara da uyarlanan özel çelik bağlantı elemanları kullanılmıştır. Elastik ahşap ızgara kabukların tüm elemanları süreklidir; montaj sürecinde ızgarayı oluşturan çıtaların itilip çekilerek oluşturulduğu aktif bükülen bu strüktürler, membran kuvvetlerini temele aktarır (Ruseler, 2017, s. 18) 
Tablo 3'te incelenen rijit ahşap ızgara kabuklarda yaşanan teknolojik gelişmeler, ızgara kabuk uygulamalarının Almanya ve İngiltere dışında Fransa ve Güney Kore'ye de taşınmasına yol açmıştır. Rijit ahşap ızgara kabuklarda; GLT (glulam, glued laminated timber), LVL (laminated veneer lumber) gibi endüstriyel yapısal ahşap bileşenler kullanılmaktadır. Kullanılan ahşap elemanlar elastik ızgaralardan farklı olarak parçalı birimlerden oluşmaktadır. Üçgen ve altıgen formlarda oluşturulan prefabrike elemanlar, rijit bir geometri oluşturduğu için elastik ızgaralardaki gibi deformasyona izin veren montaj yöntemleri kullanılmamaktadır. Fabrikada oluşturulan modüller/birimler, şantiyede geçici kalıplar kurularak birleştirilir. Bağlantı noktalarında kullanılan farkı birleşim detayları (çoğunlukla çelik) prefabrike olarak üretilir. Bu yapılarda elastik ızgara kabuklara oranla daha karmaşık elemanlardan ve detay tasarımlarından bahsetmek mümkündür. İncelenen her yapıda farklı birleşim detayı ve ızgara düzeni kullanıldığı görülmektedir. Elastik ızgaralara kıyasla daha geniş açıklıkların daha fazla yüksekliklerle geçildiği görülmektedir.

Tablo 2: Elastik ahşap ızgara kabuk örneklerinin karşılaştırılması (Chilton ve Tang, 2016; Jeska vd., 2014; Larsson, 2018; Merrick ve Harris, 2006; Quinn ve Gengnagel, 2014; Url-4).

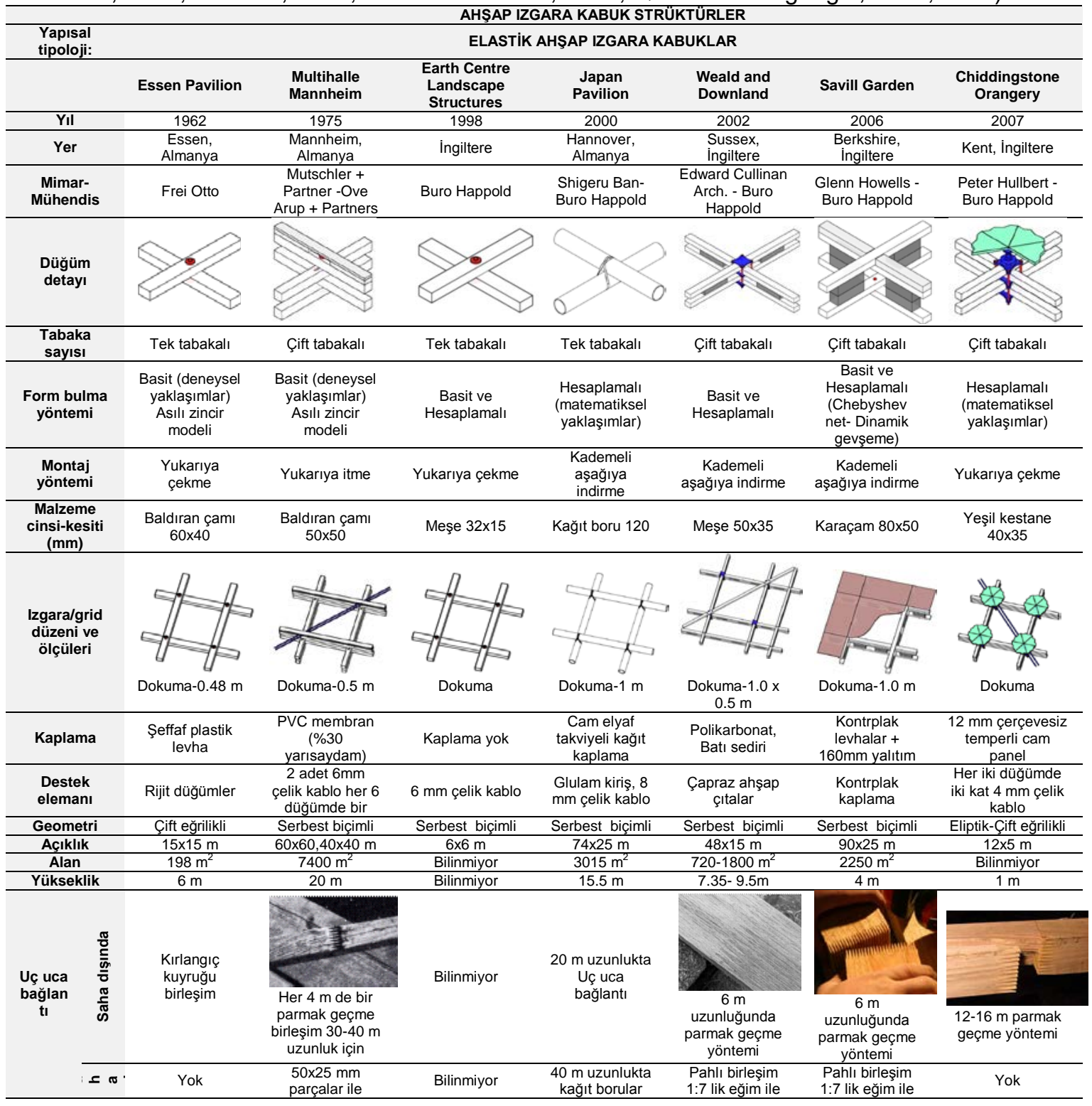


Mimaride Etkin Strüktürler Olarak Ahşap Izgara Kabuklar Timber Gridshells As Effective Structures In Architecture

\begin{tabular}{lcc} 
birleştirilmiş & birleşim $(37-50$ & birleşim \\
uzun ahşap & $\mathrm{m})$ & \\
elemanlar & & \\
\hline
\end{tabular}

Tablo 3: Rijit ahşap ızgara kabuk örneklerinin karşılaştırılması (Chilton ve Tang, 2016; Jeska vd., 2014; Larsson, 2018; Merrick ve Harris, 2006; Quinn ve Gengnagel, 2014; Url-4).

\begin{tabular}{|c|c|c|c|c|c|}
\hline & \multicolumn{5}{|c|}{ AHŞAP IZGARA KABUK STRÜKTÜRLER } \\
\hline Yapısal tipoloji: & \multicolumn{5}{|c|}{ RìIT AHŞAP IZGARA KABUKLAR } \\
\hline YıI & 2009 & 2009 & 2010 & 2013 & 2016 \\
\hline Yer & Bad Orb, Almanya & Metz, Fransa & Güney Kore & Singapur & Paris, Fransa \\
\hline Mimar-Mühendis & $\begin{array}{l}\text { Ollertz Architekten- } \\
\text { Trabert+Partner }\end{array}$ & $\begin{array}{l}\text { Shigeru Ban-Jeande } \\
\text { Gastines-Arup }\end{array}$ & $\begin{array}{c}\text { Shigeru Ban-Kyeongsik } \\
\text { Yoon-SJB Kempter Fitze } \\
\text { AG }\end{array}$ & $\begin{array}{l}\text { City Form Lab } \\
\text { ARUP }\end{array}$ & $\begin{array}{c}\text { Shigeru Ban-Jeande } \\
\text { Gastines-SJB Kempter } \\
\text { Fitze AG }\end{array}$ \\
\hline Tabaka sayısı & Tek tabakalı & Çift tabakalı & Çift tabakalı & Tek tabakalı & Çift tabakalı \\
\hline $\begin{array}{l}\text { Form bulma } \\
\text { yöntemi }\end{array}$ & $\begin{array}{c}\text { Hesaplamalı } \\
\text { (Dijital form bulma) }\end{array}$ & $\begin{array}{c}\text { Hesaplamalı (GSA } \\
\text { yazılımı) }\end{array}$ & $\begin{array}{l}\text { Hesaplamalı (Parametrik } \\
\text { model) }\end{array}$ & $\begin{array}{l}\text { Hesaplamalı } \\
\text { (3-D line network } \\
\text { software) }\end{array}$ & $\begin{array}{c}\text { Hesaplamalı } \\
\text { (Parametrik model) }\end{array}$ \\
\hline Montaj yöntemi & $\begin{array}{l}\text { Prefabrike birimlerin } \\
\text { vinçle birleştirilmesi }\end{array}$ & $\begin{array}{l}\text { Prefabrike birimlerin } \\
\text { vinçle birleştirilmesi }\end{array}$ & $\begin{array}{l}\text { Prefabrike birimlerin vinçle } \\
\text { birleştirilmesi }\end{array}$ & $\begin{array}{l}\text { Prefabrike birimlerin } \\
\text { vinçle birleştirilmesi }\end{array}$ & $\begin{array}{l}\text { Prefabrike birimlerin } \\
\text { vinçle birleştirilmesi }\end{array}$ \\
\hline Kaplama & Ahşap kaplama-30 mm & PTFE & Bilinmiyor & 2 mm galvaniz çelik & Cam kaplama \\
\hline Geometri & Serbest biçimli & Serbest biçimli & Serbest biçimli & Serbest biçimli & Çift eğrilikli \\
\hline Açıklık & $42 \times 65 \mathrm{~m}$ & $50 \times 104 \mathrm{~m}$ & $36 \times 72 \mathrm{~m}$ & Bilinmiyor & $45 \times 70 \mathrm{~m}$ \\
\hline Alan & $2200 \mathrm{~m}^{2}$ & $7000-8500 \mathrm{~m}^{2}$ & $2938 \mathrm{~m}^{2}$ & $200 \mathrm{~m}^{2-}$ & $36.500 \mathrm{~m}^{2}$ \\
\hline Yükseklik & Bilinmiyor & 36-77 m kule ile & $13,6 \mathrm{~m}-4,5 \mathrm{~m}$ & Bilinmiyor & $27.5 \mathrm{~m}$ \\
\hline \multirow{2}{*}{$\begin{array}{l}\text { Uç uca } \\
\text { bağlantı }\end{array}$} & $160-240$ mm glulam & & $9 \times 9 \mathrm{~m}$ grid & $\begin{array}{c}12 \mathrm{~mm}-1300 \mathrm{~mm} \\
\text { kontrplak }\end{array}$ & Bilinmiyor \\
\hline & $\begin{array}{l}\text { Glulam elemanların uç } \\
\text { uca bağlanması } \\
3.60 \mathrm{~m}\end{array}$ & $\begin{array}{l}\text { Glulam elemanların } \\
\text { uç uca bağlanması } \\
1-14 \text { m arası }\end{array}$ & $\begin{array}{l}\text { Pahlı birleşim yöntemi } \\
\text { yarım-bindirmeli birleşim } \\
\text { (half-lap joint) }\end{array}$ & $\begin{array}{l}\text { Kontrplak üçgen } \\
\text { modüller }\end{array}$ & $\begin{array}{c}\text { Yarım-bindirmeli } \\
\text { birleşim (half-lap joint) }\end{array}$ \\
\hline
\end{tabular}




\section{Değerlendirme ve Sonuç}

Ahşap ızgara kabuklar; en az malzeme, enerji ve giderle, öngörülen görevleri yerine getiren, uzun ömürlü ve dayanıklı, geniş açıklıklarda form esnekliği sağlayan en etkin strüktürlerden biridir. Bu sistemler, doğal, ekolojik ve yenilenebilir bir malzeme olan ahşapla inşa edilen hafif ve sürdürülebilir yapılardır.

Çalışmada incelenen örnek yapılar, yüksek yük taşıma kapasitelerine rağmen hafif olmaları ve düşük maliyetleri gibi özellikleriyle ahşap ızgara kabukların birçok olumlu yönünü göstermektedir. Aynı zamanda, teknolojinin geçmişten günümüze kadar gelişimini özetlemeye yardımcı olmuşlardır. Geçilen açıklık, sabit ve hareketli yükler, malzeme tipi ve kullanım şekli bu yapılar için önemli tasarım ölçütleridir.

Ahşap ızgara kabukların büyük ölçekli ilk örneği olan Multihalle Mannheim, deneysel tasarım süreciyle ilerleyen yıllarda yapılacak olan ızgara kabuklar için bir kılavuz olmuştur. Dijital modelleme programlarının gelişimiyle form bulma süreci kolaylaşmış ve yapım sürecinde karşılaşılabilecek sorunlar öngörülmeye başlanmıştır.

Özgün sistemler olan ızgara kabuklar, geçmişte tasarım ya da yapım aşamasında yeterli düzeyde rehber bulamadığından, yalnızca bu alanda bilgi birikimi ve tecrübesi olan birkaç büyük firma tarafından uygulanmıştır. Günümüzde Shigeru Ban Architects, Buro Happold, Ove Arup and Partners, Edward Cullinan, Glenn Howells gibi birçok mimarlık/mühendislik hizmeti veren firma ve tasarım ofisi ahşap ızgara kabukların gelişimine katkıda bulunmuştur.

Çalışmada elde edilen sonuçlara göre elastik ve rijit ahşap ızgara kabukların günümüzde sergi yapıları, spor merkezleri, tren istasyonları, endüstriyel ve ticari yapılarda kullanıldığı görülmektedir. Elastik ahşap ızgara kabuklarla ilgili yapılan değerlendirmelere göre; bu strüktürlerin ortaya çıktığı ilk dönemlerdeki örnekleri en az günümüzdeki rijit ızgara kabuklar kadar geniş açıklıkları geçebilmektedir. Bu yapıların sürekli ahşap elemanları ve tek tip bağlantı detayları standardizasyon sebebiyle maliyetin düşük olmasını sağlamaktadır. Elastik ahşap ızgara kabukların itme ve çekmeye dayanan yapım yöntemleri, geniş açıklıklı yapılarda vinç, kriko, destek elemanları gibi farklı yardımcı elemanlar gerektirdiğinden kontrolü zor bir süreç söz konusudur. Sürekli elemanların deformasyonuna bağlı olarak montaj sürecindeki ahşap bileşenlerde kırılmalar meydana gelebilmektedir. Rijit ahşap ızgara kabuklarda ise kullanılan özgün elemanlar ve gelişmiş bağlantı detayları sebebiyle maliyet elastik ızgaralara nispeten daha yüksektir. Bu yapılarda kullanılan karmaşık ve gelişmiş bağlantı detayları, farklı ahşap malzeme türleri, bu kabukların elastik ızgaralara oranla daha ağır olmasına sebep olmaktadır. Fakat gelişmiş çelik bağlantı detayları sayesinde strüktürel dayanıklılık artmaktadır. Rijit ızgara kabukların yapım yöntemlerinin, uzay kafes sistemlerine benzer şekilde olması yapım sürecini elastik ızgara kabuklara oranla kısaltmakta ve kolaylaştırmaktadır. Izgara kabukların ortaya çıktığı ilk yıllarda form bulma sürecinde deneysel form bulma yöntemleri yaygınken, günümüzde bilgisayar modelleri benimsenmiştir. Form bulma süreci, bilgisayar teknolojileri sayesinde hızlı ve kolay bir tasarım süreci haline gelmektedir. Bilgisayar modelleriyle ilerleyen form bulma süreci, henüz ön tasarım safhasında iken montaj aşamasında karşılaşılabilecek sorunların öngörülmesini mümkün hale getirmektedir. Gelişmiş yazılımlar sayesinde form yinelemeli bir süreçle optimize edilmektedir. Robotik üretim ve prefabrikasyon, yapım sürecini hızlandırmakta ve kolaylaştırmaktadır. Ahşap ızgara elemanlarının ve çelik bağlantı detaylarının üretiminde karşılaşılabilecek hatalar bilgisayar kontrollü makineler sayesinde en aza düşürülmektedir. 
Ahşap ızgara kabuklar ile ilgili literatür araştırması sonucunda konunun günümüzde gelişen teknolojiyle birlikte tekrar gündeme geldiği, bu yapıların mimari ve yapısal açıdan evrimine paralel olarak öneminin de giderek arttığı görülmektedir. Bunun sonucunda farklı tekniklerle oluşturulan ahşap ızgara kabuk sayısı artmaya devam etmektedir. Günümüzde dijital tasarım ve üretimin gelişimiyle, rijit ızgara kabukların sayısı esnek ızgara kabuklara oranla büyük ölçüde artmıştır. Yapısal karmaşıklığın zamanla artması, özgün ızgara bileşenlerinin ve düğüm noktası elemanlarının üretimine sebep olmakla birlikte; bu durum yüksek maliyetli ahşap ızgara kabukları ortaya çıkarmaktadır. Dijital üretim karmaşık elemanların yapımını kolaylaştırmakta, ancak maliyet kısıtlamaları bu özgürlüğü özel ve sembolik yapılarla sınırlandırmaktadır. Bu sınırlamalara göre, ahşap ızgara kabukların geleceğinin, farklı türdeki (ahşap, çelik, betonarme) elemanlardan oluşan hibrid yapılar olabileceği öngörülebilmektedir.

Yapım yönteminin kolaylığı sebebiyle tercih sebebi olan rijit ahşap ızgara kabukların yapısal karmaşıklığının azaltılarak, tek tip yapı elemanlarının üretilmesi ile maliyetin düşürülebileceği ve bu sistemlerden farklı işlevlerdeki yapılarda daha fazla yararlanılabileceği düşünülmektedir.

Ülkemizde ahşap ızgara kabuk yapı örneğine rastlanmamaktadır. Geleneksel ahşap yapı sistemlerimizi çağdaş yapım yöntemleriyle canlandırmak ve ahşap yapılarla ilgili farkındalığı artırmak amacıyla minimum malzemeyle oluşturulan bu etkin sistemlerden faydalanılabileceği düşünülmektedir. Çalışmanın, ahşap ızgara kabuk strüktürler ile ilgili literatür ve uygulamalara katkı sağlaması beklenmektedir.

\section{Kaynaklar}

Ağırbaş, A. (2019). A Physics-Based Design Method Of Gridshell Systems: Optimization Of Form and Construction Cost. (Doktora tezi). Yaşar Üniversitesi, Fen Bilimleri Enstitüsü, İstanbul.

Avelino, R., Baverel, O., \& Lebée, A. (2019). Design Strategies for Gridshells with Singularities. Journal of the International Association for Shell and Spatial Structures, 60, 189-200. https://doi.org/10.20898/j.iass.2019.201.023

Charest, P., Potvin, A., Demers, C. M. H., \& Ménard, S. (2019). Assessing the complexity of timber gridshells in architecture through shape, structure, and material classification. BioResources, 14(1), 1364-1378. https://doi.org/10.15376/biores.14.1.1364-1378

Charest, P., Shepherd, P., Harris, R., Potvin, andré, Demers, C., \& Ménard, S. (2019). Patchwork Gridshells: Using Modularity to Facilitate Prefabrication and Simplify Construction. Journal of the International Association for Shell and Spatial Structures, 60, 176-188. https://doi.org/10.20898/j.iass.2019.201.025

Chilton, J., \& Tang, G. (2016). Timber Gridshells Architecture, Structure and Craft. New York: Routledge.

Collins, M., \& Cosgrove, T. (2016). A Review of the State of the Art of Timber Gridshell Design and Construction. In Civil Engineering Research in Ireland. Erişim adresi http://hdl.handle.net/10344/5192

D’Amico, B. (2015). Timber Grid-shell Structures: form-finding, analysis and 
optimisation. (Doctoral dissertation). Edinburgh Napier University. https://doi.org/S0002939400009594 [pii]

Demirbaş, B., \& Girgin, Z. C. (2019). Çubuk Ağı Ahşap Kubbeler. Aurum Mühendislik Sistemleri ve Mimarlık Dergisi, 3(1), 9-21.

Fernandes, J. G., Kirkegaard, P. H., \& Branco, J. M. (2016). Tectonic Design of Timber Gridshells (pp. 2-3). Vienna, Austria.

Fritzsche, J. C. (2013). Gridshell efficiency optimization Optimizing efficiency form- \& grid-configuration through iterative approximation and minimization strain energy. (Master's thesis). Eindhoven University of Technology.

Ghiyasinasab, M., Lehoux, N., \& Ménard, S. (2017). Production phases and market for timber gridshell structures: A state-of-the-art review. BioResources, 12(4), 9538-9555. https://doi.org/10.15376/biores.12.4.Ghiyasinasab

Grönquist, P., Panchadcharam, P., Wood, D., Menges, A., Rüggeberg, M., \& Wittel, F. K. (2020). Computational analysis of hygromorphic self-shaping wood gridshell structures. Royal Society Open Science, 7(7). https://doi.org/10.1098/rsos.192210

Haddal Mork, J., Dyvik, S., Manum, B., Rønnquist, A., \& Labonnote, N. (2016). Introducing the segment lath -A simplified modular timber gridshell built in Trondheim Norway.

Happold, E., \& Liddel, I. W. (1975). Timber lattice roof for the Mannheim Bundesgartenschau. The Structural Engineer, 53(3), 99-135.

Harris, R., Kelly, O., \& Dickson, M. (2003). Downland gridshell - An innovation in timber design. Proceedings of The Institution of Civil Engineers-Civil Engineering - Proc Inst Civil Eng-Civil Eng, 156, 26-33. https://doi.org/10.1680/cien.156.1.26.36752

Harris, R., Romer, J., Kelly, O., \& Johnson, S. (2003). Design and construction of the Downland Gridshell. Building Research and Information, 31(6), 427-454. https://doi.org/10.1080/0961321032000088007

Jeska, S., Hascher, R., \& Pascha, K. S. (2014). Emergent Timber Technologies: Materials, Structures, Engineering, Projects. Basel/Berlin/Boston: Birkhäuser. Erişim adresi http://www.msgsu.edu.tr/tr-TR/universite-disindan-elektronik-kaynaklaraerisim/2023/Page.aspx

Larsson, S. (2018). Design Implications of Rigid Timber Gridshells: A Method for the Planning and Manufacture of Load-carrying, Rigid, Freeform Structures of Timber. (Master's thesis). Chalmer University of Technology.

Liddell, I. (2015). Frei Otto and the development of gridshells. In: Case Studies in Structural Engineering. (Case Studies in Structural Engineering, December 01, 2015, 4:39-49), 43. https://doi.org/10.1016/j.csse.2015.08.001

Liuti, A., \& Pugnale, A. (2015). Erection of post-formed gridshells by means of inflatable membrane technology. https://doi.org/10.13140/RG.2.2.20637.31202

Merrick, J., \& Harris, R. (2006). Glenn Howells / Savill Building. Architect's Journal, 
224(1), 25-39.

Naicu, D. (2012). Geometry and Performance of Timber Gridshells. (Master's thesis). The University of Bath. Erişim adresi http://opus.bath.ac.uk/34264/

Naicu, D., Harris, R., \& Williams, C. J. K. (2014). Timber gridshells: Design methods and their application to a temporary pavilion. Quebec City, Canada. Erişim adresi https://www.researchgate.net/publication/264539965

Paoli, C. (2007). Past and Future of Grid Shell Structures. (Master's thesis). Massachusetts Institute of Technology. Erişim adresi http://hdl.handle.net/1721.1/39277

Quinn, G., \& Gengnagel, C. (2014). A review of elastic grid shells, their erection methods and the potential use of pneumatic formwork. In WIT Transactions on the Built Environment (Vol. 136, pp. 129-144). https://doi.org/10.2495/MAR140111

Quinn, Gregory, \& Gengnagel, C. (2015). Simulation Methods for the Erection of Strained Grid Shells Via Pneumatic Falsework. https://doi.org/10.1007/978-3-31924208-8_22

Quinn, Gregory, Gengnagel, C., \& Williams, C. (2015). Comparison of Erection Methods for Long-Span Strained Grid Shells.

Ruseler, T. T. (2017). A Structural Concept for Free-Form Timber Structures. (Master's thesis). Delft University of Technology.

Songel, J. M. (2020). Sustainability lessons from vernacular architecture in Frei Otto's work: tents and gridshells. The International Archives of the Photogrammetry, Remote Sensing and Spatial Information Sciences, XLIV-M-1-2, $233-240$. https://doi.org/https://d0192efdd77670f7012d3fece2c7c0fc720c897f.vetisonline.com/10 .5194/isprs-archives-XLIV-M-1-2020-233-2020

Tang, G., Chilton, J. C., \& Beccarelli, P. (2013). Progressive Development of Timber Gridshell Design, Analysis and Construction: Paper 1387.

Türkçü, Ç. (2017). Çağdaş Taşıyıcı Sistemler. İstanbul: Birsen Yayınevi. Erişim adresi http://www.msgsu.edu.tr/tr-TR/universite-disindan-elektronik-kaynaklara-

erisim/2023/Page.aspx

Vardar Öz, Ö. M. (2012). Tek Tabakalı Uzay Kafes Sistemlerin Tasarımı. (Yüksek lisans tezi). Yıldız Teknik Üniversitesi, Fen Bilimleri Enstitüsü, İstanbul.

Willmann, J., Knauss, M., Bonwetsch, T., Apolinarska, A. A., Gramazio, F., \& Kohler, M. (2016). Robotic timber construction - Expanding additive fabrication to new dimensions. Automation in Construction, 61. https://doi.org/10.1016/j.autcon.2015.09.011

Yılmaz, D. G. (2011). Ahşap Kompozit Elemanlarla Oluşturulmuş Geniş Açıklıklı Sistemlerin İncelenmesi. (Yüksek lisans tezi). Yıldız Teknik Üniversitesi, Fen Bilimleri Enstitüsü, İstanbul.

Url-1. 18 Şubat 2021 tarihinde https://arquitecturaviva.com/works/pabellon-de-japon- 
en-expo-2000-9 adresinden alındı.

Url-2. 29 Ekim 2020 tarihinde https://www.archdaily.com/490141/centre-pompidoumetz-shigeru-ban-architects adresinden alındı.

Url-3. 18 Şubat 2021 tarihinde http://architectuul.com/architecture/nine-bridges adresinden alındı.

Url-4. 13 Kasım 2020 tarihinde http://shells.princeton.edu/Mann2.html adresinden alındı. 